\title{
Limiting horizontal water filtration using drainage-screened modules
}

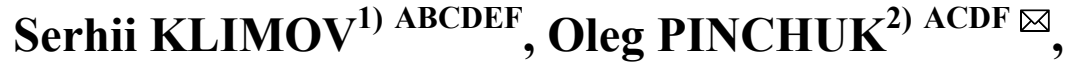 \\ Serhii KUNYTSKIY) BCEF , Anastasiia KLIMOVA ${ }^{\text {() BDEF }}$
}

1) orcid.org/0000-0002-5993-847X; National University of Water and Environmental Engineering, 33028 Rivne, Ukraine;

e-mail: s.v.klimov@nuwm.edu.ua

2) orcid.org/0000-0001-6566-0008; National University of Water and Environmental Engineering, 11 Soborna St., 33028 Rivne, Ukraine; e-mail: o.l.pinchuk@nuwm.edu.ua

3) orcid.org/0000-0003-0318-6149; National University of Water and Environmental Engineering, 33028 Rivne, Ukraine; e-mail: s.o.kunytskiy@nuwm.edu.ua

4) orcid.org/0000-0003-0051-3925; National University of Water and Environmental Engineering, 33028 Rivne, Ukraine; e-mail: a.v.klimova@nuwm.edu.ua

For citation: Klimov S., Pinchuk O., Kunytskiy S., Klimova A. 2019. Limiting horizontal water filtration using drainage-screened modules. Journal of Water and Land Development. No. 43 (X-XII) p. 90-95. DOI: 10.2478/jwld-2019-0066.

\section{Abstract}

In the context of climate change, it is important to minimize the changes that are introduced in the territory adjacent to the object of human economic activity. In some cases, this can be done with the help of drainage-screened modules - an anti-filtration screen that redistributes the zone of influence of the drain placed near it. As a result, the drain regulates to a greater extent the zone of human economic activity (drainage system, tailing dump, populated area, etc.) and to a lesser extent lowers the level of groundwater in the adjacent territory. The use of drainage-screened modules in tailing farms, for the organized storage of mineral waste of enterprises makes it possible to increase the filtration stability of dike, ensuring the uniform operation of the tailing dams, as well as reliable removal of intercepted groundwater. This is achieved because in the tailing farm the dikes are intensified by drainage-screened modules. Water, filtered through the body of the dike and under it, is intercepted by a drain. A part of the filtration flow, which is not intercepted by the drain, is stopped by the antifiltration screen.

Key words: drainage-screened modules, drainage system, tailing dump, water filtration

\section{INTRODUCTION}

In the context of climate change, the desire to maintain a balance of the environmental factors we can influence, is important not only for the human community as a whole, but also for each specific user.

The effects of economic activity change the water regime of sizeable territories [GRAMLICH et al. 2018; TUOHY et al. 2018].

Sometimes, due to design mistakes or insufficient studies and, accordingly, incorrect consideration of existing conditions, or when primary conditions have changed over time, economic activity leads to negative changes [EVANS 2016; MARTYNIUK et al. 2018].

For Ukraine, this is particularly noticeable - the cultivated lands make up $65 \%$ of the total land [YATSYK et al. 2007], the natural damper is absent, and human activities significantly affect the composition and regime of the waters.

In Ukraine, the area of drained land is $9.7 \%$ of the total area of arable lands. About $60 \%$ of swamps, waterlogged areas and wetlands have been drained. Not all of $2 \mathrm{mln}$ ha of drainage systems currently operate with sufficient efficiency. Negative changes in the adjacent territories are 
mostly felt on drainage systems with one-sided regulation (only water drainage). Drainage systems lead to a decrease of groundwater levels in the adjacent areas, which affects negatively $22 \%$ of the areas in the influence zone.

According to the research data of MASLOV and MINAEV [1985], the size of the influence zone of drainage systems is comparable to the dimensions of the dehumidification areas. Ten years after the building of a drainage system, the width of the impact zone can reach 1.0-1.2 km. With the close location of several reclamation systems, the influence zones can overlap with a corresponding increase up to 3-6 km [MASLOV, MiNAEV 1985].

Gradients of the groundwater flow grow in the adjacent territory and the underground component of the river flow increases [BOMBA et al. 2018; SMEDEMA et al. 2004; VAN DER MOLEN et al. 2007]. Dehumidification of swamps or adjoining areas leads to sedimentation of peat and an increase in surface slopes towards water receivers, which contributes to an increase in surface runoff. On adjacent peatlands, the risk of fires increases.

Peat deposits are an important link in the ecological system of regions and the whole planet, and therefore, it is very promising to introduce peat extraction technologies and further transfer them to the category of renewable resources.

A decrease in groundwater levels and dehumidification of wetlands adjacent to meliorated lands contributes to the removal of chemical elements from the soil.

Swamps are known to play a significant role in the gas balance of the Earth's atmosphere. Studies show that old drained peat deposits generate a significant amount of harmful "greenhouse" methane $\mathrm{CH}_{4}$ [HNYEUSHEV 2004], which leads to an intensification of the greenhouse effect. To reduce the $\mathrm{CH}_{4}$ emissions, partial flooding of the deposits is proposed, which reduces the amount of over-dried peat. The use of peat deposits with the organization in the form of a cycle is proposed in the National University of Water and Environmental Engineering (NUWEE, Natsional'nyy universytet vodnoho hospodarstva ta pryrodokorystuvannya) in such a way that, in a certain area of the region, works on the preparation of deposits for the development, extraction of peat, re-waterlogging, forging and storing accumulation were carried out in such volumes and in such a sequence that the total reserves of peat in the region remain steady. To implement these principles, it is necessary to create several sites on one peat field, which will support a different level of groundwater. On some sites, the development of old peat deposits will be carried out, and on the other, young deposits, the conditions will be created for the intensive formation of peat, which in the course of their development will effectively absorb another "greenhouse" gas - $\mathrm{CO}_{2}$ from the atmosphere almost without producing methane.

The mining industry in Ukraine is a source of pollution of surface and groundwater.

Moreover, the impact on the environment does not stop even after the cessation of mining operations (postmining damage).

Despite constant searches and obtaining new opportunities for using tailings, the problem of their accumulation and negative impact on the natural environment still re- mains urgent [Poswa, DAVIES 2017; QUAGHEBEUR et al. 2013; TSCHUSCHKE et al. 2017].

One of the aggravating factors of environmental impact is that in Ukraine, a small part of the tailings has a reliable anti-filtration shielding, resulting in a filtration loss of up to $40 \%$ of water discharge.

The proposed solution relates to the reconstruction of tailing dump elements and is aimed at reducing, and ideally eliminating the negative impact on the environment.

\section{MATERIAL AND METHODS}

For anti-filtering protection of the areas adjacent to tailing storages and sludges, walls, screens, diaphragms, curtains combined with drainage are used. Drainage system is composed of multi-floor circumferential drainage, drainage of the starter dam, drainage ditches at the dam toe and the barrier of deep-drainage wells at the close forefield [TSCHUSCHKE et al. 2017].

A significant protective role is played by the decant systems.

The use of drainage-screened modules (DSM) in tailing farms, for the organized storage of mineral waste of enterprises makes it possible to increase the filtration stability of dike, ensuring the uniform operation of the tailing dams, as well as reliable removal of intercepted groundwater.

This is achieved by the fact that in the tailing storages, which consist of alluviation maps, the dikes are intensified with a DSM. Water, filtered through the body of the dike and under it, is intercepted by a drain (Fig. 1).

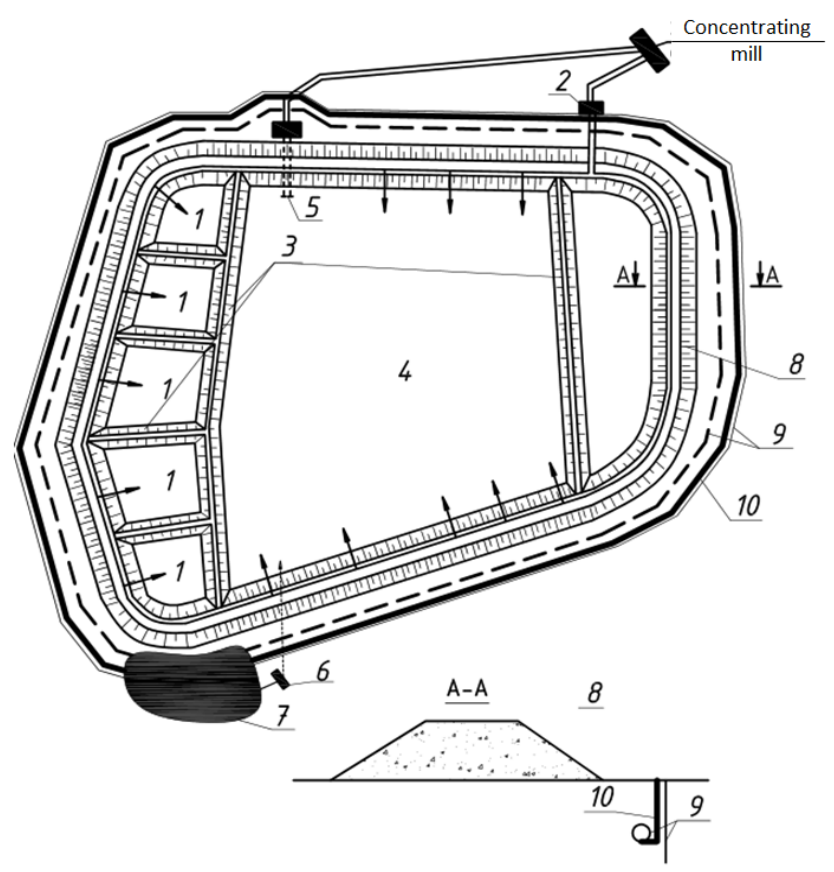

Fig. 1. Tailing farms with the drainage-screened module, reinforced by drainage element: $1=$ storage pool; $2=$ pulp pump station; $3=$ internal dams; $4=$ settler pond; $5=$ water diversion structure; $6=$ pumping station of drainage water;

$7=$ accumulating capacity of drainage water; $8=$ embankment wall; $9=$ drainage-screened module (DSM); $10=$ drain element; source: own elaboration 


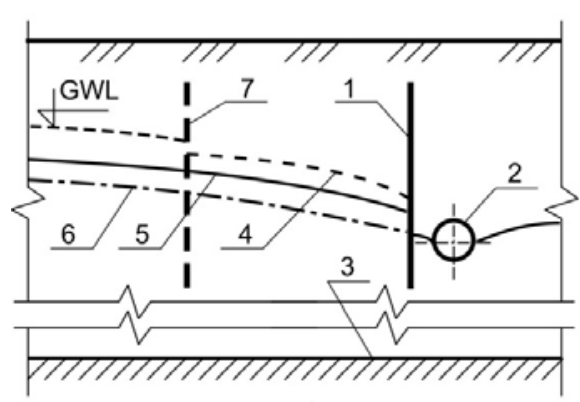

a)

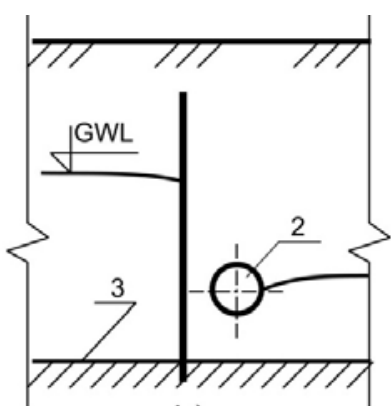

b)

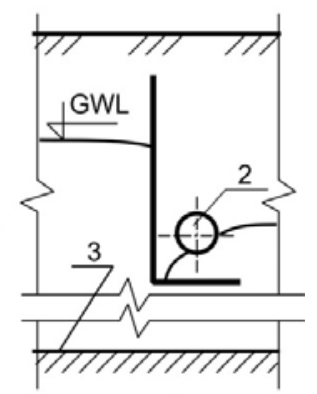

c)

Fig. 2. Layout schemes of anti-filtration screen (AFS) as part of the drainage-screened modules (DSM): a) with a deep location of the aquiclude with the possible device additional AFS with significant filtration flow rates; $b$ ) at low powers of the aquifer and the possibility of penetrating the AFS into the local aquiclude; $c$ ) the device of an additional horizontal part of the screen; $1=$ anti-filtration screen; $2=$ drain; 3 = aquiclude; 4, 5, $6=$ levels of groundwater, respectively, with two AFS, with one AFS and without AFS; GWL = ground water level; source: own elaboration

Part of the filtration flow, which is not intercepted by the drain, is stopped by the antifiltration screen (AFS). The DSM on the side of the dike may additionally be equipped with a draining element that is hydraulically connected to the drain, which ensures an organized accelerated drainage of groundwater into the drain, substantially reducing the possibility of waterlogging the downstream part.

The NUWEE researchers have developed a drainage-screened module, which consists of a drain and an AFS, placed at a close distance from the drain along its entire length (Fig. 2). The AFS creates a one-side resistance to the underground filtration water flow and the drain intercepts this reduced flow [KLIMOV 2018].

When calculating parameters, the DSM was based on the assumption that loss of water pressure when it comes from the undrained area [MARTYNOV et al. 2018; SAFONYK et al. 2018]:

1) losses on groundwater filtration (losses per distance);

2) losses for creating a resistance on the AFS (local losses) that can be determined using the basic law of laminar filtration (Darcy's formula).

The motion of groundwater under the AFS laminar and is consistent with Darcy's law, in addition, it is steady, uneven, that is characterized by the presence of curvilinear living cross sections.

Next we consider the hydrogeological conditions, when the soil is homogeneous, the aquiclude with varying degrees of influencing it on the hydrological situation of the area, in particular, it is a nearby located aquiclude, which significantly influences the formation of the ground water level (GWL) on the territory: $T<10 \mathrm{~m}, D A F S / T>$ $0.4, T / E_{1}<3$ ( $T$ is the average thickness of the groundwater layer intercepted by the drains (m); DAFS is the depth of the bottom edge of the AFS (m)).

Total flow of the drain (Fig. 3):

$$
q=q_{1}+q_{2}
$$

Where: $q_{1}$ is the influx of groundwater from the undrained area to the drains under the screen; $q_{2}$ is the influx of groundwater from the drainage area.
For example, when DSM operates as an edge drain of the drainage system, the following option is possible:

$$
\begin{aligned}
& q_{1}=\omega k \frac{b-b_{1}}{b+b_{1}} \\
& q_{2}=\frac{2 \pi k H_{2} L_{d r}}{\ln \frac{4 t_{d r}}{d}+C}
\end{aligned}
$$

Where: $\omega$ is the area of the living cross section under the screen; $H=b-b_{1}$ is the decrease of pressure; $b+b_{1}$ is the length of the wetted underground circuit along the screen on both sides; $H_{2}$ is the pressure in the drained area; $L_{d r}$ is the length of the drain; $\ln \frac{4 t_{d r}}{d}$ is the filtration resistance of the ideal drain; $C$ is the additional filtration resistance of the real drain which is imperfect by the nature of the opening of the aquifer.

To calculate the influence of the parameters DSM (distance from AFS to drains, from AFS to aquiclude) on the efficiency of its work (falling pressure of the filtration flow on AFS), we apply the method of fragments.

The method proceeds from the fact that the flow of water to the drain bypassing the AFS is a complex filtration area in which it is possible to draw lines close to the lines of equal pressures that divide the filtration region into separate parts-fragments, the forms of which are relatively simple and for which there are precise solutions. To deter- 
mine the dependence of the component of the total drainage flow on the AFS from the pressure at a certain distance from the screen using the "approximate" method of fragments, these solutions interconnect the equality of the water quantity that flows through them. We distinguish three characteristic zones of motion of the filtration stream from the environment to the drains in the composition of DSM (from the AFS), which are connected in series (Fig. 4). Taking into account the equality of the water flow through these fragments, the following relationship the following formula for pressures on the AFS was deducted:

$$
b_{1}=-b \frac{\left(b_{n}+b\right)^{2}-H_{1}^{2}+2 b_{n} L_{1}}{\left(b_{n}+b\right)^{2}-H_{1}^{2}-2 b_{n} L_{1}}
$$

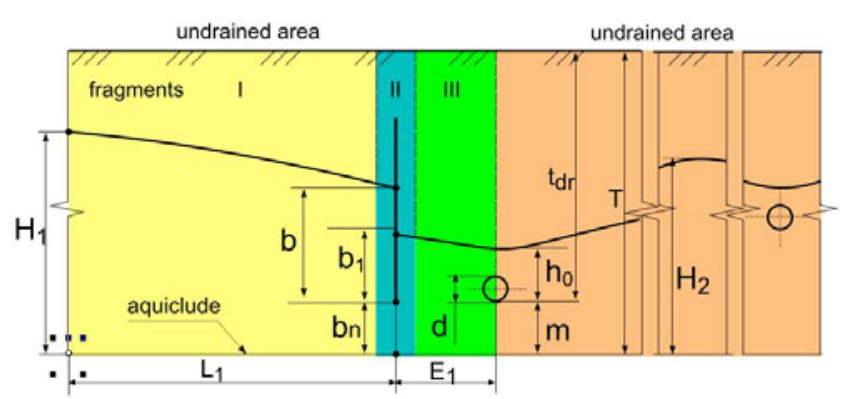

Fig. 4. The scheme for calculating parameters of drainage-screened module using the method of fragments;

$H_{1}=$ the pressure in the undrained area at a distance $L_{1}$; $\mathrm{H}_{2}=$ the pressure in the drained area between the two utmost drains; $E_{1}=$ distance from the drain to the anti-filtration screen

(AFS); $b=$ pressures on the AFS from the undrained area; $b_{1}=$ pressures on the AFS from the drainage area;

$b_{n}=$ the distance from the lower edge of the anti-filtration screen to the aquiclude, $m=$ the distance from the drainage to the aquiclude; $T=$ the average thickness of the groundwater

layer intercepted by the drains; $t_{\mathrm{dr}}=$ depth of drainage;

$h_{0}=$ the pressure atop the drain; $d=$ diameter of the drain; source: own elaboration

Applying the quasi-Newton method, with the help of the computer algebraic system (CAS), possible solutions to the next equality are found:

$$
\begin{gathered}
\frac{H_{1}^{2}-\left(b_{n}+b\right)^{2}}{2 \cdot L_{1}}=b_{n} \cdot \frac{b-b_{1}}{b+b_{1}}= \\
=\frac{\left[\left(b_{1}+b_{n}-m\right)-h_{0}\right] \cdot m}{E_{1}} \cdot \frac{\pi}{2} \cdot \frac{1+0.8 \ln \left(\frac{E_{1}}{m}\right)}{\ln \left(\frac{2 \cdot E_{1}}{d}\right)-1}+\frac{\left(b_{1}+b_{n}-m\right)^{2}-h_{0}{ }^{2}}{E_{1}} .
\end{gathered}
$$

\section{RESULTS AND DISCUSSION}

We investigated the influence of the main parameters of drainage-screened module (DSM) on its effectiveness and provided relevant recommendations for the introduction to the state agency on water resources of Ukraine (Derzhavne ahentstvo vodnykh resursiv Ukrayiny). An increase in the depth of insertion of the lower edge of the AFS leads to the decrease in drainage from the adjoining undrained areas and partial increase from the part of the reclaimed area due to the decrease in the hydraulic load on the drain from the adjoining undrained areas (Fig. 5). In general, drainage effluent with an increase in the ratio of $b_{n}: m$ from $0.37 \mathrm{~m}$ to $1.56 \mathrm{~m}$ increases from 14.4 to 18.5 $\mathrm{cm}^{3} \cdot \mathrm{s}^{-1}$. An increase in the distance from the drain to the anti-filtration screen (AFS) leads to the reduction in the flow of the undrained area (environment) and partial increase from the part of the drained area, with the total drainage drop (Fig. 6). This is due to the increase in the pressure drop on the AFS.

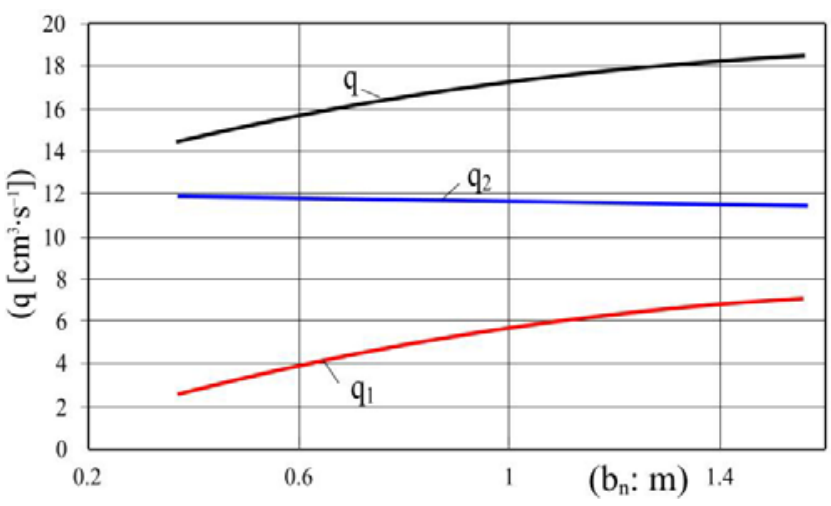

Fig. 5. The dependence of drainage flow from the undrained areas $q_{1}$ and from the drained area $q_{2}$, total drainage flow from the relative depth of insertion of the lower edge of anti-filtration screen; $b_{n}=$ the distance from the lower edge of the anti-filtration screen to the aquiclude, $m=$ the distance from the drainage to the aquiclude; source: own study

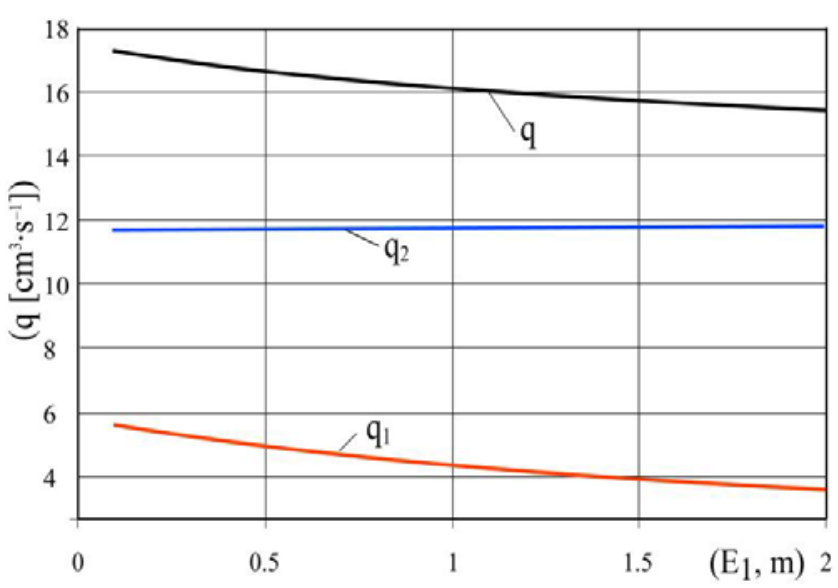

Fig. 6. The dependence of drainage flow from the undrained areas $q_{1}$ and from the drained area $q_{2}$, total drainage flow from the distance from the drain to the anti-filtration screen $E_{1}$; source: own study

When increasing the distance to the aquiclude, the drainage from the drain increases (see Fig. 7). At the same time, an increase in drainage effluent occurs both from the undrained area $q_{1}$ and from the side of the drained area $q_{2}$, with the more intensive increase of runoff from the undrained area, which is explained by the decrease in the resistance, which creates AFS for the filtration flow with the decrease in its compression. It is most clearly observed with the decrease in the ratio $E_{1}: m<0.25$, and then the increase in runoff slows down. 


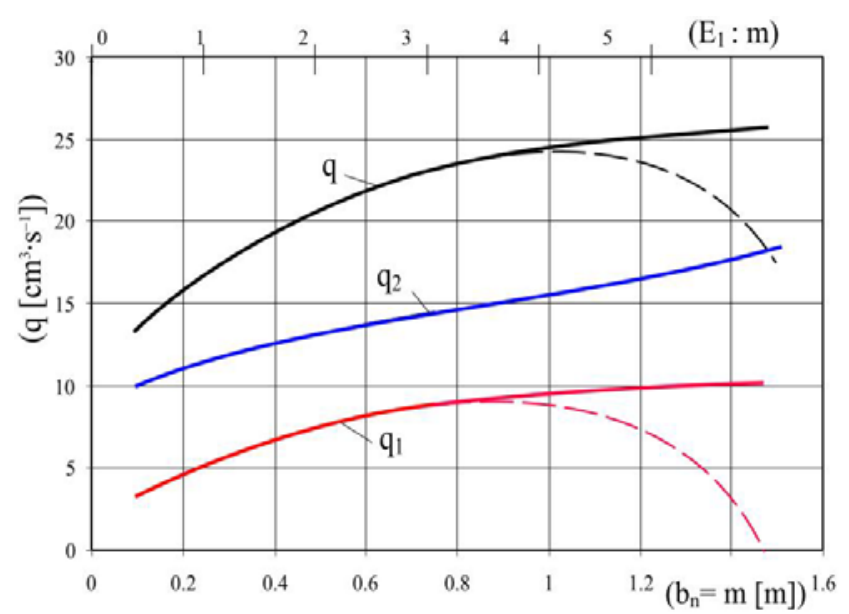

Fig. 7. The dependence of drainage flow from the undrained areas $\left(q_{1}\right)$ and on the drained area $\left(q_{2}\right)$, the total drainage effluent from the relative depth of insertion of the lower edge of anti-filtration screen $E_{1}: m$; source: own study

\section{CONCLUSIONS}

The mathematical dependencies obtained allow us to create DSM constructs with given parameters optimally adapted to specific hydrological conditions. Drainage-screened modules provide ground water level (GWL) regulation on a drained site in accordance with production needs - more water is diverted from conventional drainage. At the same time the level of ground water on the territory adjacent to the economic activity is higher than on the site itself (at the same distance from the drains) reaching by $0.15-0.25 \mathrm{~m}$, which indicates a decrease in their mutual influence.

The use of DSM in cases where drainage systems lead to an undesirable decrease in the groundwater level in the adjacent territories, will allow to localize the to dehydrate effect of the drainage, to create an artificial damper for human effects on the natural groundwater regime.

Installation DEMs on the wetland border will reduce greenhouse gas emissions by reducing peat over-drieding and reducing the likelihood of pollutants entering groundwater at tail farms.

\section{REFERENCES}

Bomba A., Tkachuk M., Havryliuk V., Kyrysha R., Gerasimov I., PinchuK O. 2018. Mathematical modelling of filtration processes in drainage systems using conformal mapping. Journal of Water and Land Development. No. 39 (X-XII) p. 11-15. DOI 10.2478/jwld-2018-0054.

EvANS I.S. 2016. Quantifying variation in wetland composition and configuration for landscape-scale reclamation planning [online]. Master thesis. Waterloo, Ontario. University of Waterloo pp. 102. [Access 03.01.2019]. Available at: http://hdl. handle.net/10012/10985
Gramlich A., Stoll S., Stamm C., Walter T., Prasuhn V. 2018. Effects of artificial land drainage on hydrology, nutrient and pesticide fluxes from agricultural fields - A review. Agriculture, Ecosystems and Environment. Vol. 266 p. 8499. DOI 10.1016/j.agee.2018.04.005.

HNyeusheV V. 2004. About the transformation of peat into a renewed resource. Publisher International Peat Society. No. 2 p. 54-55.

KLIMOV S.V. 2018. Lokalizacija vplyvu osušuval'nych system zastosuvannjam drenažno-ekrannych moduliv: Monografiya [Location of the influence of drainage systems with using drainage-screened modules. Monograph]. Rivne. NUVGP. ISBN 978-966-327-372-3 pp. 249.

Martyniuk P.M., Kutia T.V., OSTAPChUK O.P., Pinchuk O.L. 2018. Filtration equation and movement of the wetting interface in case of pressure pipeline breakthrough under the conditions of variable porosity. JP Journal of Heat and Mass Transfer. Vol. 15. Iss. 2 p. 281-293. DOI 10.17654/ HM015020281.

Martynov S., FylypchuK V., Zoshchuk V., Kunytsky S., SAFONYK A., PINCHUK O. 2018. Technological model of water contact iron removal. Journal of Water and Land Development. No. 39 (X-XII) p. 93-99. DOI 10.2478/jwld2018-0063.

Maslov B.S., MinAev I.V. 1985. Melioratsiya i okhrana prirody [Land reclamation and nature conservation]. Moskva. Rosselhozizdat pp. 271.

Poswa T., DAvies T. 2017. The nature and articulation of ethical codes on tailings management in South Africa. Geosciences. Vol. 7. No. 4 p. 1-28. DOI 10.3390/geosciences7040101.

Quaghebeur M., Laenen B., Geysen D., Nielsen P., Pontikes Y., Gerven T., SpoORen J. 2013. Characterization of landfilled materials: Screening of the enhanced landfill mining potential. Journal of Cleaner Production. Vol. 55 p. 72-83. DOI 10.1016/j.jclepro.2012.06.012.

Safonyk A., Martynov S., Kunytsky S., PinchuK O. 2018. Mathematical modelling of regeneration the filtering media bed of granular filters. Advances in Modelling and Analysis C. Vol. 73. No. 2 p. 72-78. DOI 10.18280/ama_c. 730206 .

Smedema L.K.,Vlotman W.F., Rycroft D. 2004. Modern land drainage: Planning, design and management of agricultural drainage systems. CRC Press. ISBN 9789058095541 pp. 462.

TschuschKe W., WróŻYŃSKA M., WIERZBICKI J. 2017. Quality control for the construction of a tailings dam. Acta Geotechnica Slovenica. Vol. 17. No. 1 p. 3-9.

Tuohy P., O'Loughlin J., Peyton D., Fenton O. 2018. The performance and behavior of land drainage systems and their impact on field scale hydrology in an increasingly volatile climate. Agricultural Water Management. Vol. 210 p. 96107. DOI 10.1016/ j.agwat.2018.07.033.

VAN Der Molen W.H., Martínez Beltrán J., OChS W.J. 2007. Guidelines and computer programs for the planning and design of land drainage systems. FAO Irrigation and Drainage Paper. No. 62. Rome. FAO. ISBN 978-92-5105670-7 pp. 228.

Yatsyk A., Hryshchenko Yu., Volkova L., Pasheniuk I. 2007. Vodni resursy: Vykorystannja, ochorona, vidtvorennja, upravlinnja [Water resources: Use, protection, reproduction, management]. Kyiv. Heneza. ISBN 978-966-504-708-7 pp. 360 . 


\section{Serhii KLIMOV, Oleg PINCHUK, Serhii KUNYTSKIY, Anastasiia KLIMOVA}

Ograniczanie poziomej filtracji wody za pomocą modułów ekranów drenarskich

\section{STRESZCZENIE}

W obliczu zmian klimatu ważne jest minimalizowanie zmian wprowadzanych na obszarach sąsiadujących z obiektami gospodarczej działalności człowieka. W niektórych przypadkach można to osiągnąć za pomocą modułów ekranów drenarskich - ekranów zapobiegających filtracji, które przekształcają strefę wpływu drenów w sąsiedztwie. W wyniku ich działania dren w większym stopniu reguluje strefę gospodarczej działalności człowieka (systemy drenarskie, odcieki z hałd, tereny zamieszkałe itp.), a w mniejszym zakresie obniża poziom wód gruntowych w okolicy. Zastosowanie modułów w przedsiębiorstwach zajmujących się zagospodarowaniem mineralnych odpadów przemysłowych umożliwia zwiększenie stabilności filtracyjnej grobli zapewniając wyrównane działanie zbiorników odciekowych oraz kontrolowane usuwanie przejętej wody gruntowej. Taki efekt osiąga się, ponieważ w omawianych zbiornikach groble są wzmacniane przez moduł ekranowy. Woda filtrująca przez groblę lub pod nią jest przejmowana przez dreny. Część filtrującej wody, której nie przejęły dreny, zatrzymuje się na ekranach zapobiegających filtracji.

Słowa kluczowe: filtrowanie wody, moduly ekranów drenarskich, odcieki z hałd, system drenarski 